Journal of Environmental Sciences (JES)

Institute of Environmental Studies and Research, Ain Shams University

Hamed Abbass et al.

\title{
ASSESSMENT OF FUTURE WATER, ENERGY, AND FOOD NEXUS BY USING WEAP AND LEAP MODELS IN THE STATE OF KUWAIT
}

\author{
Hamed A. Abbas ${ }^{(1)}$; Sayed M. Elkhouly ${ }^{(2)}$ \\ and Meshari L. Al-Harbi ${ }^{(3)}$
}

1) Post graduate student at Institute of Environmental Studies and Research, Ain Shams University 2) Faculty of Commerce, Ain Shams University 3)College of Life Sciences, Kuwait University

\begin{abstract}
With the global population growing (over seven billion), accompanied by escalating economic crises, mismanagement of natural resources, climatic changes, and uncertainties, and increasing poverty and hunger, the world is opposing critical periods of serious challenges. This paper aims to develop an integrated dynamic model for the WEF system for all governances in the State of Kuwait and future demand with and without climate change. Additionally, identifying proper opportunities in the WEF system in Kuwait. The aim is achieved by building an integrated dynamic model and analyzing it via using WEAP and LEAP software. The business as usual scenario concluded that increasing water, energy, and food within the next 17 years for all governorates. Besides that, climate change will also affect increasingly upon the WEF system. The impact is expected to rise, on average between 2 to $4 \%$ in the period 2017-2035 with total cumulative demand about 3144 Mm3. By using several interventions, management policies would help the water, energy, and food system to ensure its sustainability. The several interventions, such as reducing per capita consumption, saving devices, population control, and using reverse osmosis technology, will reduce the demand by about $50 \%$ by the year 2035 .
\end{abstract}

Keywords: water, energy, and food nexus; WEAP and LEAP; climate change. 
Journal of Environmental Sciences (JES)

Institute of Environmental Studies and Research, Ain Shams University

Hamed Abbass et al.

\section{INTRODUCTION}

With global population growing (over seven billion), accompanied with escalating economic crises, mismanagement of natural resources, climatic changes, and uncertainties, and growing poverty and hunger, the world is opposing critical period of serious challenges. These challenges are linked with social, economic, and political threats to present and future generations. Different studies including water, food, energy, trade, climate, and population growth nexus attempt to determine the relationship between the latter environmental (eco)systems. The innovation of those nexuses results from realizing the multi-dimensional and interdisciplinary nature of the predicted challenges (Daher, 2012).

Water, Energy, and Food (WEF) are strongly linked, correlated and each recognized as a vital input to modern economies. In recent years, driven by the three imperatives of security of supply, sustainability, and economic efficiency (Hussey \& Pittock, 2012). Achieving WEF security is a critical challenge confronting the Gulf Cooperation Countries (GCC). In addition, population growth has raised WEF demands and supply costs; climate change has increased the attention to environmental issues, and natural disasters and military conflicts have placed WEF security under evolving pressure (Jalilov, Amer, \& Ward, 2013). Recently, the nexus approach has been widely recognized. This method is identifying two or more resources that are often broadly defined regarding water, energy or food within a particular geographic or sociopolitical boundary (Villamayor-Tomas, Epstein, Evans, \& 496 
Journal of Environmental Sciences (JES)

Institute of Environmental Studies and Research, Ain Shams University

Hamed Abbass et al.

Kimmich, 2015). Water Evaluation and Planning (WEAP) and the Longrange Energy Alternatives Planning (LEAP) System are friendly and widely used as integrated mathematics software developed by the Stockholm Environment Institutes. To build an integrated water and energy modeling platform by linking two separated modeling tools WEAP and LEAP were developed and used in this research.

\section{PROBLEM STATMENT}

State of Kuwait is classified as water stressed with limited natural water resources (less than $500 \mathrm{~m} 3 /$ capita) (Falkenmark, 1990). After oil era, water and energy supply management have faced several challenges to meet socioeconomic needs including increasing in population, economic and industrial development, changing in lifestyle. In return, Kuwait government refuge into unconventional resources such as water desalination and power plants that utilizing fossil fuel in early 1950s.

Water demand has been increasing gradually in the last twenty years (total consumption of fresh water increased from $260 \mathrm{~mm} 3$ in 1994 to 728 mm3 in year 2017) (MEW, 2017). The potable water is secured by distilled seawater, blended with brackish water $3-7 \%$, which is subsequently delivered to domestic, industrial, and agriculture sectors. The desalinated water, using MSF method, is usually combined with power plants that are an energy intensive technology. Thus, increasing desalinated water lead to increase energy requirements. The fossil fuel consumption in power desalination 
Journal of Environmental Sciences (JES)

Institute of Environmental Studies and Research, Ain Shams University

Hamed Abbass et al.

plants rose from 29 to 44 million/barrel during 2008 - 2014 (MEW, 2015).

Collected sewage effluents, pumping into treated plants, and treated wastewater from Kuwait city and its suburbs are also required enormous energy alongside transfer treated wastewater into farms.

\section{RESEARCH QUESTIONS}

Due to the research problem, the following questions are determined:

1. How can the changing in the climate might effect on water and energy resources? And what is the environmental cost?

2. Can the technology and awareness policies sustain the water, energy, and food consumption?

3. Is controlling in population growth sustain the water, energy, and food demand?

\section{RESEARCH AIMS}

This paper aims to develop an integrated mathematical dynamic model for WEF system for all governances in the State of Kuwait and future demand with and without climate change. Also, determining the incremental impact (environmental impact). Additionally, to identifying good opportunities in WEF system in Kuwait. The aim is achieved via building an integrated dynamic model and analyzing by using WEAP and LEAP software.

\section{RESEARCH SIGNIFICANT}


Journal of Environmental Sciences (JES)

Institute of Environmental Studies and Research, Ain Shams University

Hamed Abbass et al.

Water, energy, and food security is sensitive key for building a sustainable economy. In fact, a high level of interconnectedness exists between the three resources which have to be taken into consideration. These resources are affected by external factors such as a growing population, changing economies, urbanization, and climate change.

Thus, recognizing the intimate connection between WEF resources is necessary to move to more integrative and sustainable approach for resource management by identifying the its cost whether environmentally within the overall system.

\section{LETRETURE REVIEWS}

WEAP software: According to SEIa, 2018 and Kelemework, (2018) WEAP is a water resource management tool designed to simulate water supply and demand system, policy scenarios analyses, integration planning approach.

Amin, et al. (2018) emphasized that WEAP tool provides a set of procedures and platform to solve water problems by helping the decision makers and managers to sit up optimum policies by using a scenario-based approach.

Besides that, Slaughter and Mantel, (2018) highlighted that WEAP model is proven an extensive successful model for quantity in data poor rejoins, water quality analysis, and catchment area management.

Kishiwa, et al. (2018) focused on the role of changing the climate and its influence on the natural resources. It is a valuable model for analyzing 
Journal of Environmental Sciences (JES)

Institute of Environmental Studies and Research, Ain Shams University

Hamed Abbass et al.

impacts of climate change on water resources and looking for good management and planning through adaptation alternatives as well as sensitivity analyses for forecasting stages.

According to Kou, et al. (2018) WEAP is considered a strategy frame to develop water supply and demand perspectives for long-range period embed ecosystem preservation.

LEAP software: On the other hand, SEIb (2018), mentioned that LEAP is a powerful tool for energy policy analysis and climate change mitigation assessment adopted by many countries, academic and non-academic organization and companies.

(Kim 2018) This tool is also utilized to predict and analyze the environmental impacts of changes, electricity generation technologies and its cost and compare all variables in numerous scenarios. Furthermore, it is effective tool provides the decision makers several scenarios about energy supply and demand within long-range to sit up suitable policies to meet socioeconomic needs.

A more comprehensive description can be found in a Chovert and Alonso (2017) research where energy consumption, production, and extraction of resources are the main functions for LEAP and it can be also conducted in all the sectors of an economy.

AlSabbagh, et al. (2015) concluded that LEAP is user-friendly, can be modeled with limited data, and does not require substantial expertise to develop models. 
Journal of Environmental Sciences (JES)

Institute of Environmental Studies and Research, Ain Shams University

Hamed Abbass et al.

Interlinkages between WEAP and LEAP software: According to Alberta (2018) WEAP-LEAP models are integrated models help decision-makers, managers, and researchers to assess the coherence of relevant policies and to explore opportunities to achieve sustainable development. For sustainable energy, many countries try to implement mega projects by moving towards a cleaner electricity grid to mitigate climate change such as adopting hydropower technology.

A coupled WEAP-LEAP are used to simulate the water and energy supply and demand to improve the understanding the holistic picture about WEF linkages and trade-off. In addition, these models are utilized to analyze the impact of power generation (hydropower) on water system according to Kelemework (2018) and Dawoud (2018). Also, the tow researches highlighted about how much energy has needed to produce water by using desalination power plant.

Sieber and Heaps (2017) designed a holistic framework that illustrates the linkage between water and energy issues in an integrated dynamic model as shown in Figure (1). The main idea is focusing on the water and energy supply side and demand side considering the conventional and unconventional recourse that utilized in the WEF system.

Moreover, Li (2014) employed the WEAP-LEAP software as a holistic tool to study Water, Energy, and Food system interconnection. And this interconnection might be addressed by using WEAP and LEAP tools to investigate the trade of between the three pillars. 
Journal of Environmental Sciences (JES)

Institute of Environmental Studies and Research, Ain Shams University

Hamed Abbass et al.

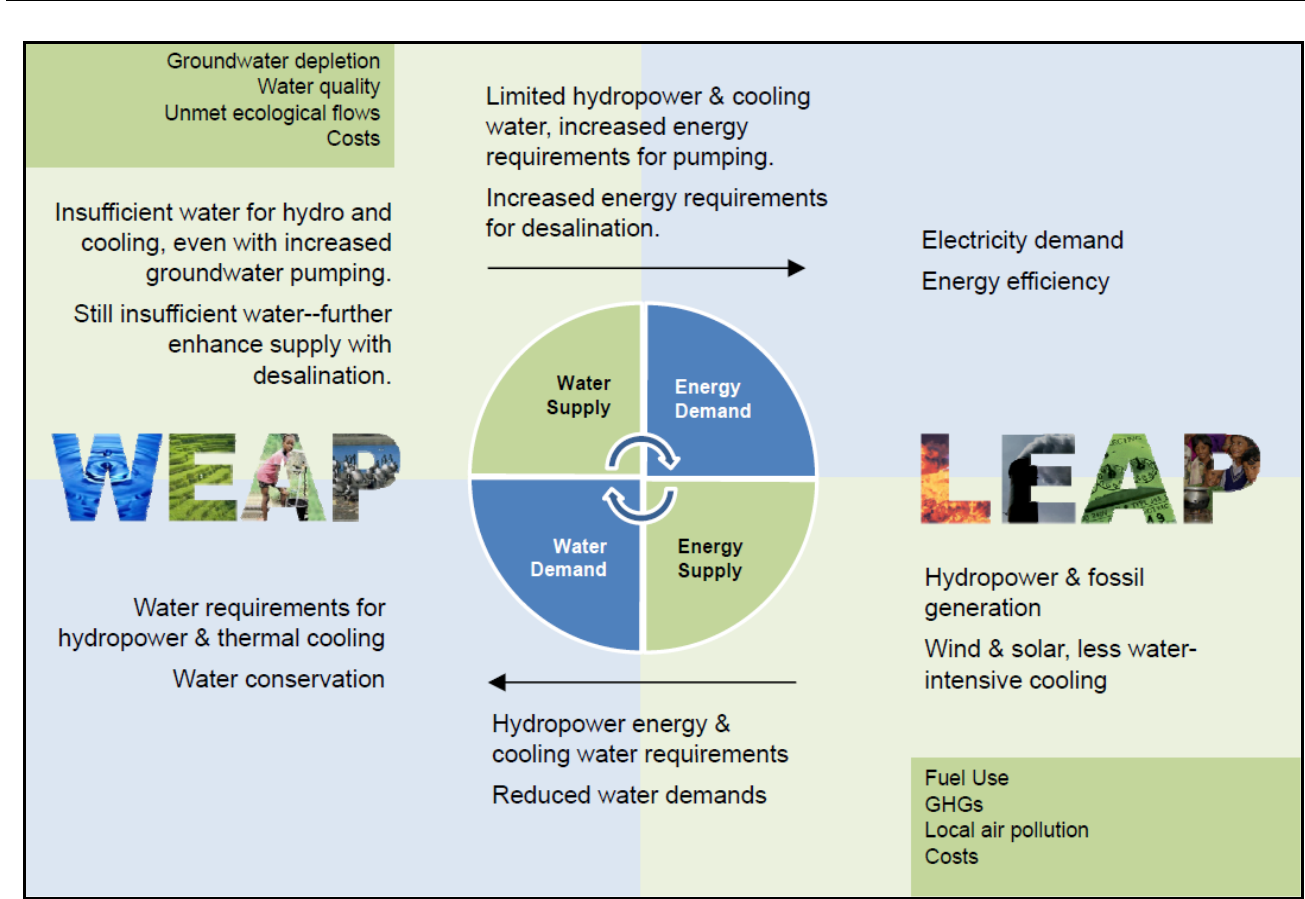

Figure (1): Conceptual linking WEAP and LEAP models (Sieber and Heaps, 2017)

\section{THEORETICAL FRAMEWORK}

Quantifying the trade of between WEF nexus is still in early stage specially in Arid zones. Therefore, investigating the interlinkages between the three pillars by using WEAP-LEAP tool is good practice for water, energy, and food management in arid zones Kuwait as a case study.

\section{RESEARCH METHOD}


Study sample and Calculations: This is a primary study on WEF system as presented in figure (2), which includes supply and demand and its transmissions within the six governorates (Al-Asma, Hawalli, Al-Jahra, AlFarwanya, Mubarak, and Al-Ahmadi) in Kuwait and two agricultural areas (Al-Abdalli and Al-Wafra). Demand side is represented in red points. Whereas supply side includes green square refers to groundwater and desalination, then maroon circle demonstrates treated wastewater plants (Sulabia, Kabd, Al-Jahra, Al-Wafra, Um-Alhayman, Rigga, and Al-Khairan). The WEAP model transaction passes to LEAP model (Figure 5-3) to analyze electricity consumption. Then LEAP model calculate environmental impact associated with greenhouses gases.

The water, energy, and food system models were developed based on the following equations:

$$
\mathcal{A D}=\sum\left(\sum \mathcal{G}\right) n+\left(\sum \mathcal{A}\right) n \quad 1
$$

Where:

$\mathscr{A D}=$ Annual Demand

$\mathcal{G}=$ Total water demand in all governorates

$\mathcal{A}=$ Total water demand in all agriculture areas

To calculate total water demand in each governorate by followed equation

$\mathcal{G}=\sum \mathcal{P} \times \mathcal{C}-\mathcal{W} \mathcal{L}$

Where: 


$$
\begin{aligned}
& \mathcal{P}=\text { Population } \\
& \mathcal{C}=\text { Annual water consumption per capita } \\
& \mathcal{W L}=\text { Water losses }
\end{aligned}
$$

To calculate total water demand in the agriculture sector by followed equation

$$
\mathcal{A}=\sum \mathcal{A} \mathcal{R} \times \mathcal{C} \mathcal{A}
$$

Where:

$$
\begin{aligned}
& \mathcal{A} \mathcal{R}=\text { Planted area } \\
& \mathcal{C} \mathcal{A}=\text { Annual water consumption per hectare }
\end{aligned}
$$

To calculate the electricity consumptions, it is a must to calculate the volume of water production from desalination plants, wastewater treatment, groundwater extraction as well as water pumping quantities from desalination plants through domestic consumption then water inflow and treatment after that water conveying to agriculture areas whether from desalination and treatment plants. This be done as in the following equation:

$$
\mathcal{T E}=\sum \mathcal{A D}+\mathcal{W} \mathcal{P}+\mathcal{W E}+\mathcal{W} \mathcal{T}
$$


Journal of Environmental Sciences (JES)

Institute of Environmental Studies and Research, Ain Shams University

Hamed Abbass et al.

Where:

$\mathcal{T E}=$ Total electricity

$\mathcal{A D}=$ Annual water demand production

$\mathcal{W} \mathcal{P}=$ All water pumping

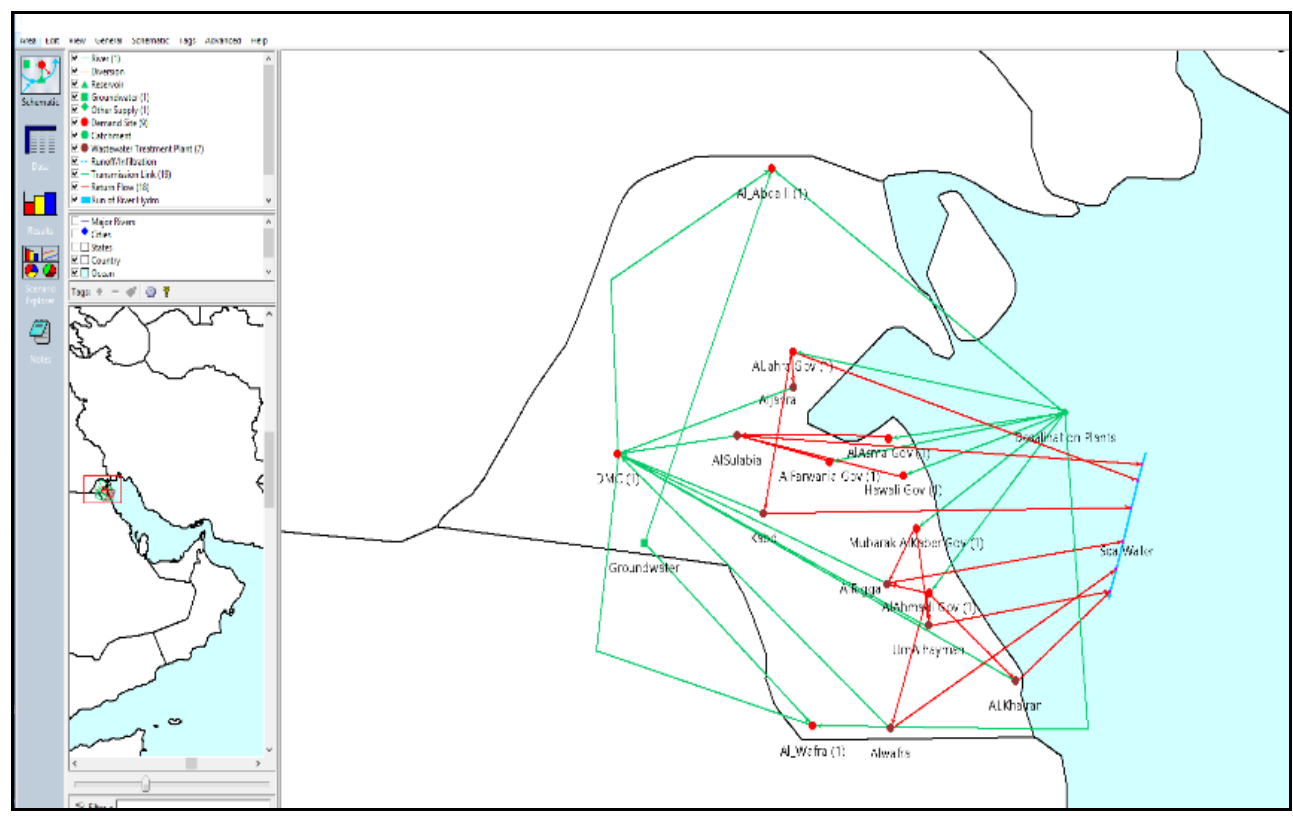

Figure (2): WEAP Conceptual Dynamic Model 


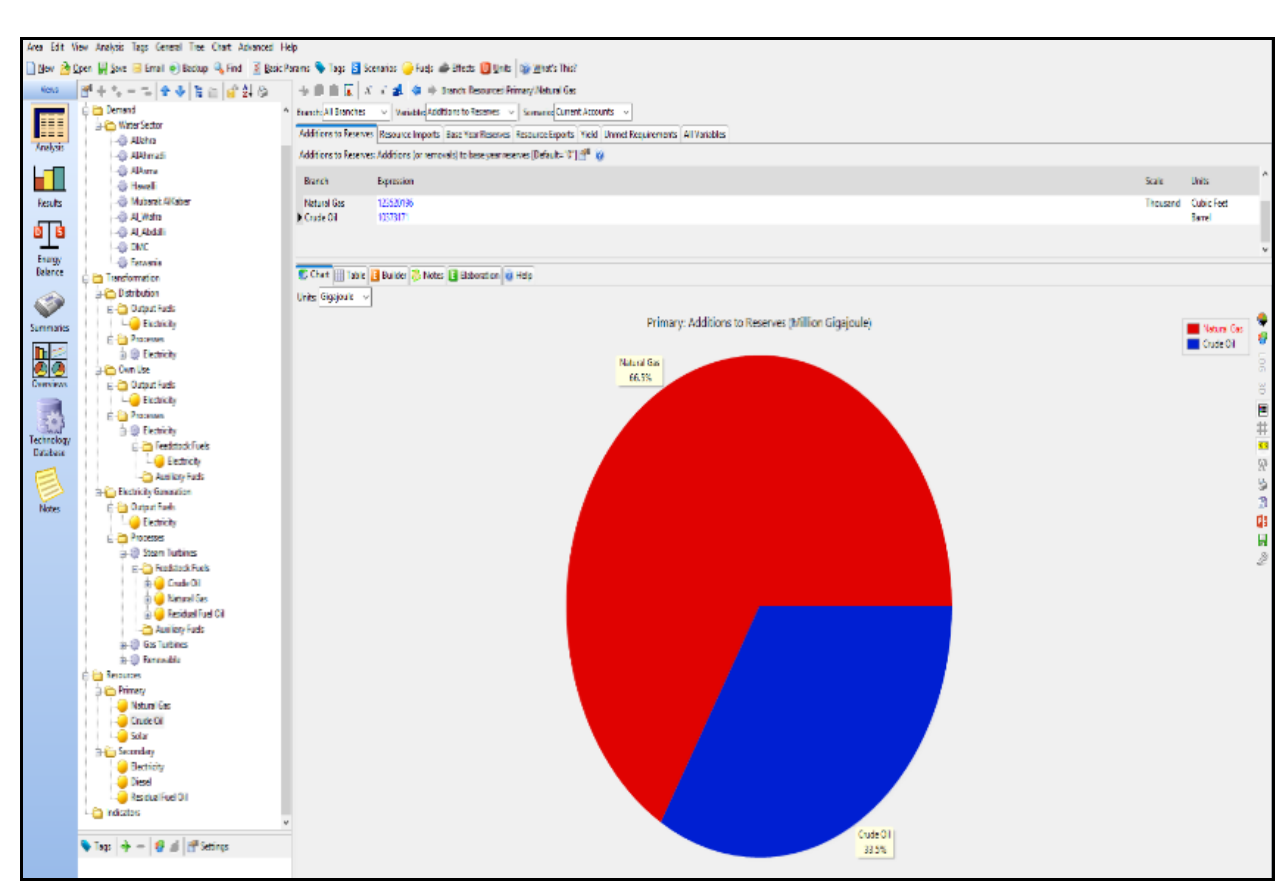

Figure (3): LEAP linkages with WEAP model

\section{ASSUMPTIONS AND LIMITATIONS}

WEAP-LEAP model input for Business As Usual (BAU) scenario was used as the initial information for research carried out as demonstrated in the table (5-1). The impact of climate change on water demand sectors was built in the WEAP model by using the average temperature trends and projections in the State of Kuwait from 2006 to 2035 using general circulation model (GCM) as represented in figure (5-4). This model is developed by the Canadian Center for Climate Modelling and Analysis ( Salzen, et al. 2013). 
To figure out the impact of climate change on water demand, a regression intercept model was used as shown in the equation shown below:

$$
\mathcal{A}=\bar{y}-\mathcal{B} \bar{X}
$$

Where:

$\mathcal{B}=$ slope is calculated as the equation following:

$$
\mathcal{B}=\frac{\sum(x-\bar{x})(\mathcal{Y}-\bar{y})}{\sum(x-\bar{x})^{2}} \quad 6
$$

Where:

$\mathrm{x}=$ average temperatures

$\mathrm{y}=$ average water demand

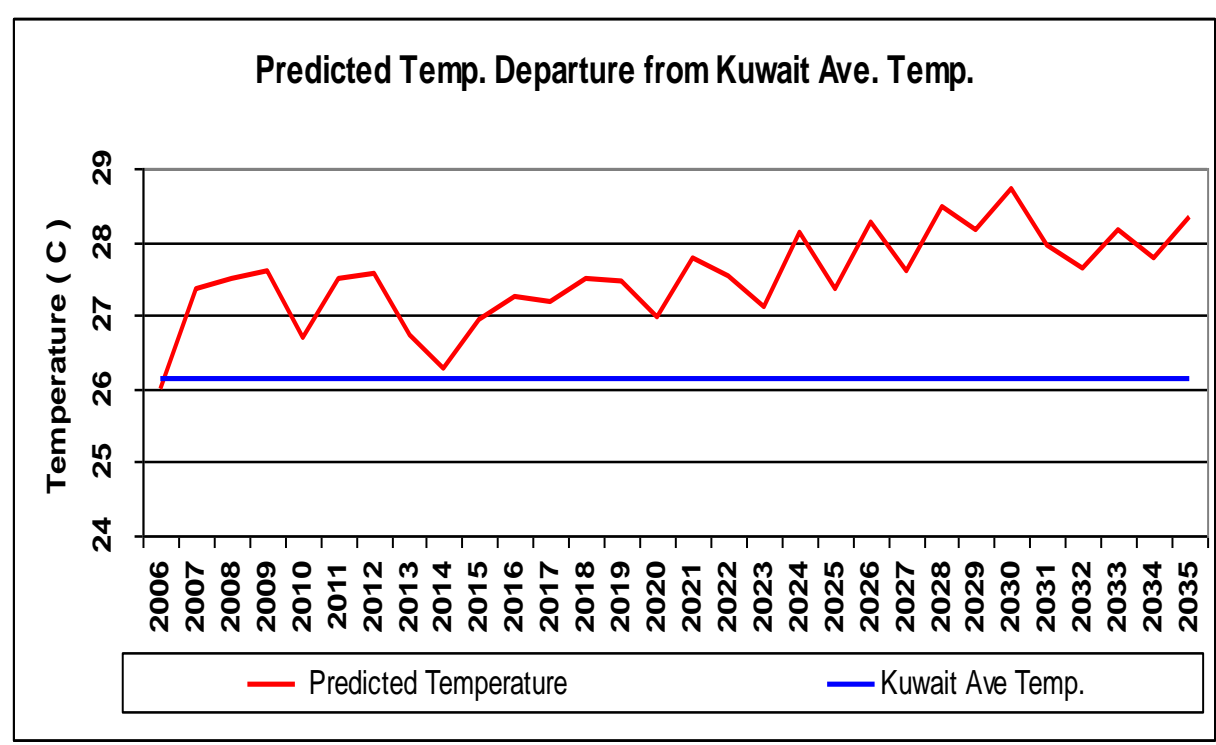

Figure (Error! No text of specified style in document.): projection of temperature during 2006-2035 
Source: (DGCA 2017)

Table (1): WEAP and LEAP Assumptions

\begin{tabular}{|c|c|c|c|}
\hline Domestic sector & $\begin{array}{c}\text { Annual } \\
\text { population } \\
\text { growth rate }\end{array}$ & $\begin{array}{c}\text { Per capita } \\
\text { consumption } \mathbf{m}^{3} \text { / } \\
\text { year }\end{array}$ & $\begin{array}{c}\text { Water } \\
\text { consumption in } \\
\text { demotic sector } \\
\text { (\%) }\end{array}$ \\
\hline Al-jahra & 3 & 175.8 & 51 \\
\hline Al-ahmadi & 3.5 & 119 & 53 \\
\hline Al-asma & 1.5 & 139 & 60 \\
\hline Hawalli & 3 & 107 & 60 \\
\hline Mubarak al-kaber & 2.1 & 342 & 53 \\
\hline Al-farwanya & 3 & 81 & 60 \\
\hline $\begin{array}{c}\text { Agriculture sector } \\
\text { Al-abdalli }\end{array}$ & $\begin{array}{c}\text { Annual growth } \\
\text { rate }\end{array}$ & $\begin{array}{c}\text { Per hectare } \\
\text { consumption } \\
\text { thousand m³/year }\end{array}$ & \\
\hline Al-wafra & 2 & 30 & \\
\hline $\begin{array}{c}\text { Electricity required for } \\
\mathrm{m}^{3}\end{array}$ & $\mathrm{Kwh} / 1 \mathrm{~m}^{3}$ & & \\
\hline $\begin{array}{c}\text { Fresh water production } \\
\text { and pumping }\end{array}$ & 20 & & \\
\hline $\begin{array}{c}\text { Extracting and } \\
\text { treatment }\end{array}$ & 4 & & \\
\hline $\begin{array}{c}\text { General assumptions: } \\
\text { Water losses (\%) }\end{array}$ & 15 & & \\
\hline
\end{tabular}

\section{RESULTS AND DISCUSSION}

\section{Business as Usual Scenario:}

This scenario predicts water demand for both domestic and agriculture sectors, as well as the energy required for water production and pumping. Figure (5) illustrates water demand in all governorates which is predicting 
Journal of Environmental Sciences (JES)

Institute of Environmental Studies and Research, Ain Shams University

Hamed Abbass et al.

water increase from $70 \mathrm{Mm}^{3}$ to $180 \mathrm{Mm}^{3}$ in Al-Ahmadi, less quantity in Hawalli, then Al-Farwania. That means population distributions in those areas are increasing due to the growth of non-Kuwaiti population. In addition to that, the water demand projections might be increased in the agriculture sector from 350 and $120 \mathrm{~mm}^{3}$ to 513 and $450 \mathrm{Mm}^{3}$ in Al-Abdalli and AlWafra during the period 2006-2035, respectively.

Due to an increase in water demand, the energy consumption would be raised. As presented in figure (6) energy required for producing, pumping, and extraction water for domestic and agricultural peruses will increase during the next 19 years. Socio-economic needs are the mean driving forces for increasing water demand followed by energy consumption. The electricity consumption for water requirements is expected to increase from 396 to 915 thousand $\mathrm{kWh}$ for the period 2006-2035, which means increasing on average about $3 \%$ annually. Therefore, expansion of urbanization implicates to increase water demand such as new areas in northern and southern Kuwait City as mentioned in $4^{\text {th }}$ Kuwaiti Master Plan and Public Authority for Housing Welfare strategy.

Al-Ahmadi, Hawalli, and Al-Farwania governorates are the largest consumers of water due to non-Kuwaiti residences live in those governorates and expansions of urban areas especially in Al-Ahmadi, for example, new areas in southern of Al-Ahmadi governorates such as Subah Al-Ahmad and south Subah Al-Ahmad cities, Al-Wafra expansion, and Al-Khiran City. Public Authority For Housing Welfare is conducting a mega project which is 
Al-Mutla area in Al-Jahra governorate includes about twenty-five thousand housing units within coming years. Besides that, the demand might be increased faster due to carry out the north Kuwait project (Silk City). This project is part of Al-Jahra governorate.
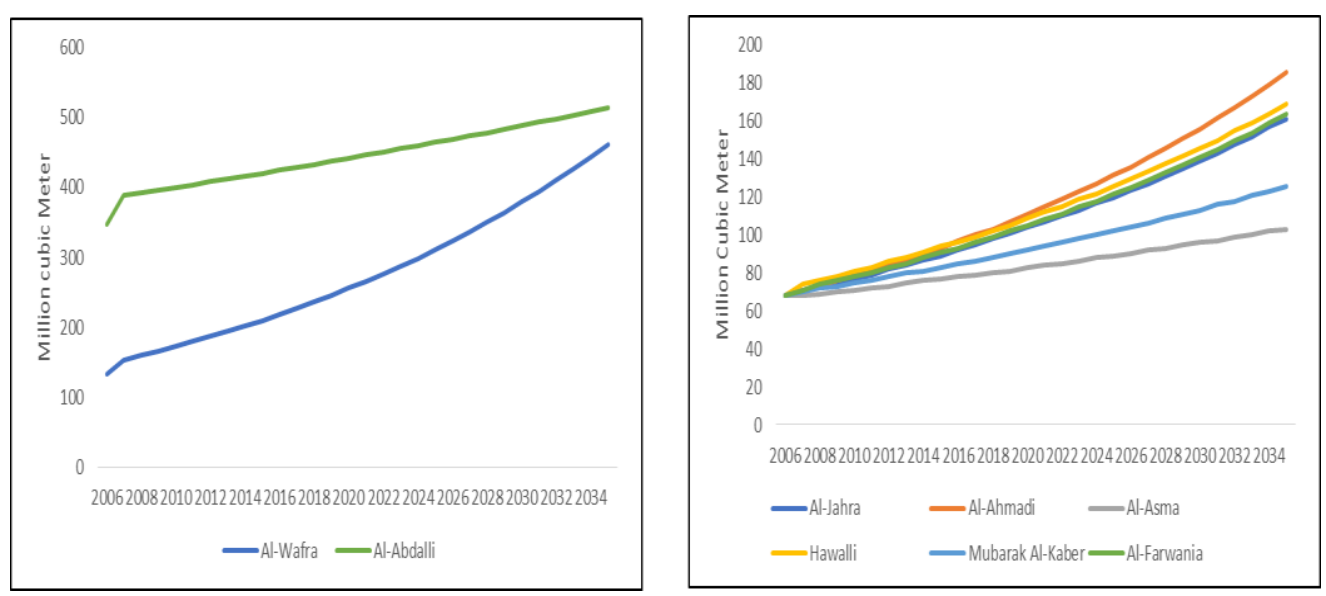

Figure (4): Water demand predictions in domestic and agriculture sectors
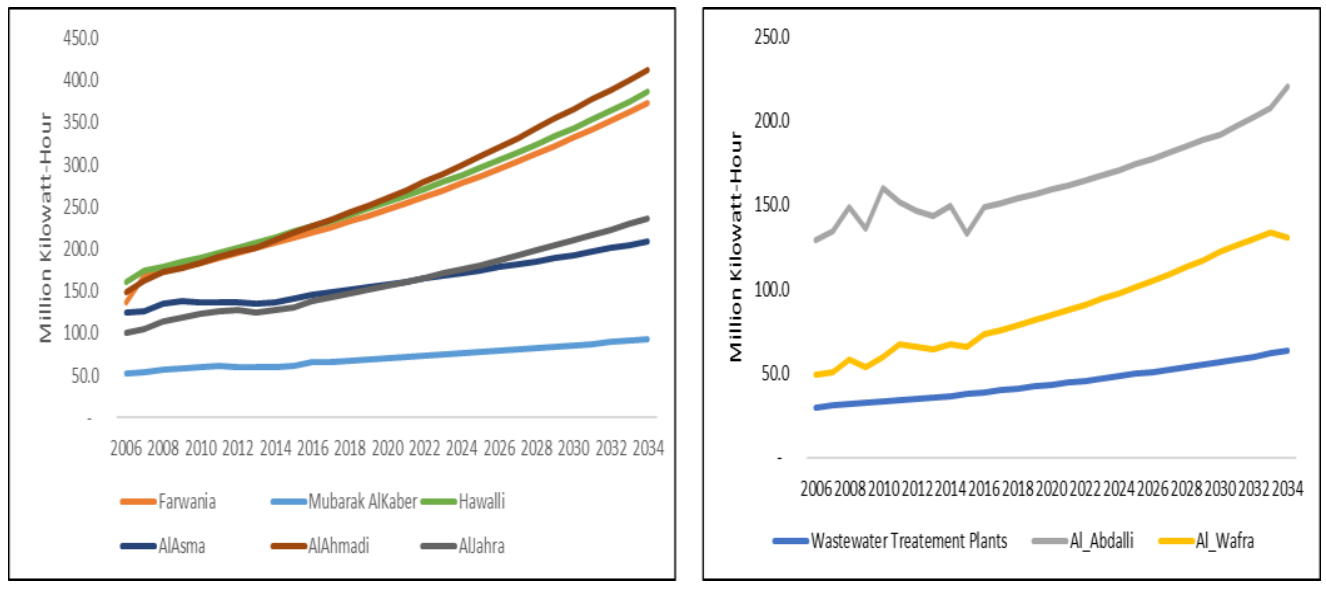
Journal of Environmental Sciences (JES)

Institute of Environmental Studies and Research, Ain Shams University

Hamed Abbass et al.

Figure (5): Predictions of electricity consumption in the domestic and agriculture sector

\section{Climate Change Scenario:}

The changing in climate would be impacted on water resources in the next 17 years in the State of Kuwait. Table (3) illustrates the additional burden of the impact of $\mathrm{CC}$ on all governorates. The impact is expected to rise in average between 2 to $4 \%$ in the period 2017-2035 with total cumulative demand about $3144 \mathrm{Mm}^{3}$. This figure clarifies that increases one degree will increase about $14 \mathrm{Mm}^{3}$ in corresponding. Al-Ahmadi and Hawalli then Al-Farwania are the biggest governorates damaged from changing in climate whereas Al-Asma is the smallest exposure to climate change. The impact of climate change on urban areas is indirectly due to the main reason refer to water consumption patterns.

The agriculture sector is the largest deteriorated from climate change implication. Due to continuing of incremental temperatures, the water demand in Al-Abdalli and Al-Wafra would be increased from 477 and 333 to 561 and $461 \mathrm{Mm}^{3}$ respectively by 2035 as shown in table (3). Even though Al-Abdalli area is experienced higher water consumption compared with AlWafra area, it is obvious that Al-Wafra area is highly impacted from changing of climate than Al-Abdalli area.

The climate change will not only affect the water system but also it indirectly affects energy system. Climate change impact has increased on water demand within current pattern. That increasing would effect on 
Journal of Environmental Sciences (JES)

Institute of Environmental Studies and Research, Ain Shams University

Hamed Abbass et al.

electricity that required to produce water, especially in the domestic sector. Table (3) shows also the average increase of electricity within the climate change, it is about $4 \%$ annually. Al-Farwania is the largest consumer for the electricity then Al-Ahmadi, where the consumption will increase from 299 and 242 to 518 and 556 million kWh for the period 2017-2035 respectively. Hawalli and Al-Jahra are the second consumers for electricity; the average consumption would be increased from 241 and 139 to 502 and 334 million $\mathrm{kWh}$ respectively for the same period. Moreover, Al-Asma and Mubarak AlKaber are the smallest consumers for the electricity as illustrated in the same table.

Agriculture sector as mentioned in previous chapters depends on three water resources; desalination, groundwater, and reclaimed water. All these resources need electricity to produce water to meet food needs. In the agriculture sector. The electricity consumption in Al-Abdali farms will increase from 149 in 2017 to 253 million $\mathrm{kWh}$ in the year 2035. With total average is about $4 \%$ for the next 17 years. Furthermore, Al-Wafra farms would consume double between period 2017-2035 in an average of consumption by about $6 \%$ in the same period. That concluded that the southern area such as Al-Wafra could be impacted more than Al-Abdalli which is located northern area. 
Table (2): Impacts of Climate change on the WEF system for the years 2017 $-2035$

\begin{tabular}{|c|c|c|c|c|c|c|}
\hline \multirow{2}{*}{} & \multicolumn{2}{|c|}{$\begin{array}{c}\text { Water } \\
\text { (MCM) }\end{array}$} & \multicolumn{2}{c|}{$\begin{array}{c}\text { Electricity } \\
\text { (MKWH) }\end{array}$} & \multicolumn{2}{c|}{$\begin{array}{c}\text { Co2 Emission } \\
\text { (KT) }\end{array}$} \\
\cline { 2 - 7 } & $\mathbf{2 0 1 7}$ & $\mathbf{2 0 3 5}$ & $\mathbf{2 0 1 7}$ & $\mathbf{2 0 3 5}$ & $\mathbf{2 0 1 7}$ & $\mathbf{2 0 3 5}$ \\
\hline \hline Al-Jahra & 126 & 192 & 139 & 334 & 342 & 521 \\
\hline Al-Ahmadi & 139 & 225 & 242 & 556 & 377 & 611 \\
\hline Al-Asma & 91 & 115 & 146 & 249 & 247 & 312 \\
\hline Hawalli & 132 & 202 & 241 & 502 & 358 & 549 \\
\hline Mubarak Al-Kaber & 105 & 145 & 65 & 132 & 286 & 394 \\
\hline Al-Farwania & 128 & 196 & 299 & 519 & 364 & 531 \\
\hline Al-Wafra & 333 & 566 & 73 & 155 & 904 & 1033 \\
\hline Al-Abdalli & 477 & 561 & 149 & 253 & 1537 & 1524 \\
\hline
\end{tabular}

\section{Alternatives for WEF Sustainability:}

One of the main objectives in this research is to ensure that the sustainability of water, energy, and food system in the State of Kuwait. Sustainability can be achieved through changing current policies and focusing on demand side via adopting adequate alternatives. Reducing per capita consumption, using water saving devices, and controlling population growth are the appropriate alternatives for managing the WEF system in the domestic sector. On the other hand, there are four alternatives scenarios for managing agricultural sector. These includes reduction per hectare consumption, increase irrigation efficiency, land use control, using advanced technology, and the combination between alternatives as presented in table (4).

The per capita consumption reduction scenario assumed that rising public awareness through water conservation campaigns, education sector, worship 
places, ministries, and shopping centers. The water saving devices scenario assumed that whether privet, public buildings or malls using saving devices would decrease water consumption. The third scenario assumed that population growth (decreasing numbers of immigrants) should be controlled especially unskilled labors. Despite the difficulty of this option, it is one of the alternatives presented to the views of many parliament members. The fourth scenario assumed that reverse osmosis technology would be utilized to produce fresh water from desalination plants. This scenario will help to reduce final energy intensity to produce desalted water. The management interventions assumed that all alternatives would be adopted.

Table (3): Options for managing WEF systems

\begin{tabular}{|c|c|}
\hline Alternative & Unit \\
\hline \multicolumn{2}{|l|}{ Domestic Sector: } \\
\hline Reducing per capita consumption every five years & 5-liter reduction per day \\
\hline Using water saving devices & $20 \%$ reduction \\
\hline Population control in each governorate & $0.005 \%$ reduction \\
\hline $\begin{array}{l}\text { Using reverse osmosis technology (energy model } \\
\text { only) }\end{array}$ & Six kwh \\
\hline All alternatives & $\begin{array}{c}\text { Include all alternatives } \\
\text { measurements }\end{array}$ \\
\hline \multicolumn{2}{|c|}{ Agricultural Sector: } \\
\hline $\begin{array}{c}\text { Reducing per hectare consumption every five } \\
\text { years }\end{array}$ & 10 thousand $\mathrm{m}^{3}$ per year \\
\hline Increasing irrigation efficiency & $20 \%$ \\
\hline Land use control & $0.005 \%$ reduction \\
\hline Using reverse osmosis technology (energy only) & Six kwh \\
\hline All alternatives & $\begin{array}{l}\text { Include all alternatives } \\
\text { measurements }\end{array}$ \\
\hline
\end{tabular}


The results from testing deferent alternatives ensure that reach the targets by the year 2035. Adopting per capita consumption reduction policy will reduce water demand from $50 \%$ in the next 17 years. Whereas adopting water saving devices and population control will help to decrease the total demand from $2 \mathrm{Bm}^{3}$ to 1.6 and $1.7 \mathrm{Bm}^{3}$ respectively at the end of year 2035 . Moreover, the implementation of management interventions (all alternatives) would contribute in reducing the water demand by $52 \%$. Figure (7) shows the calculated model results in the Al-Jahra governorate; the water demand would decrease via adapting per capita consumption alternative, water saving, population control will shift from $161 \mathrm{Mm}^{3}$ to 123,128 , and $140 \mathrm{Mm}^{3}$ by 2035 respectively. Similarly, the rest of governorates water demand would decrease due to implementing user`s alternatives. Thus, to improve sustainability in the all sectors the consideration to demand-side management better than follow supply management such as the expansion of desalination plant to meet socio-economic needs. 
Hamed Abbass et al.

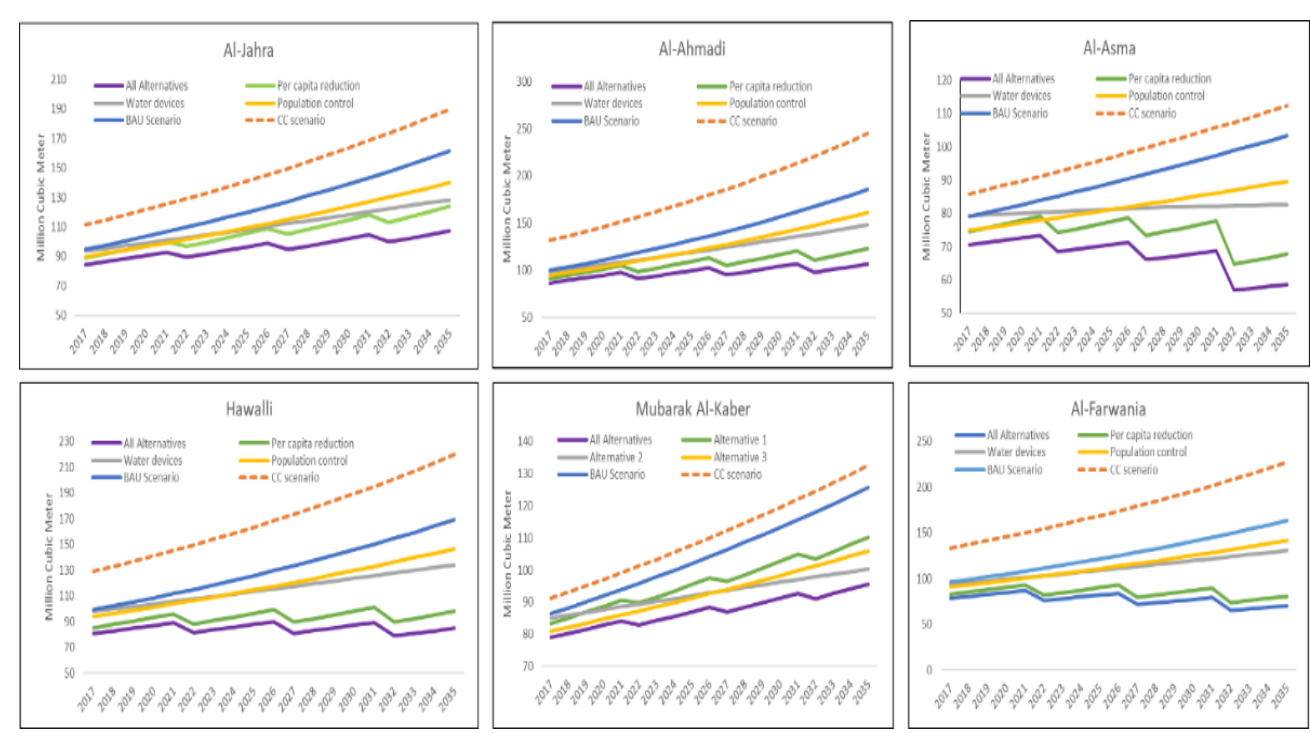

Figure (6): Results of WEF management

Figure (8) illustrates the calculated model results in the agriculture sector by utilizing different options scenario. The total water demand in Al-Wafra catchment will decrease from $563 \mathrm{Mm}^{3}$ in BAU scenario to $230 \mathrm{Mm}^{3}$ in per hectare reduction by year 2035, followed by agriculture land control by 348 $\mathrm{Mm}^{3}$. Moreover, using irrigation efficiency would decrease the water demand to reach about $369 \mathrm{Mm}^{3}$. Therefore, using intervention management by adopting all alternatives; the water consumption will reduce in total about 174 $\mathrm{Mm}^{3}$ in the year 2035. Similarly, per hectare reduction, which is a strategic option, will contribute for reducing water demand from $747 \mathrm{Mm}^{3}$ to 341 $\mathrm{Mm}^{3}$. Correspondingly, the irrigation efficiency, a strategic alternative, would decrease the water demand to $546 \mathrm{Mm}^{3}$ at the end of the year 2035. Whereas, 
implementing land control will reduce water consumption to $600 \mathrm{Mm}^{3}$ in the same year.
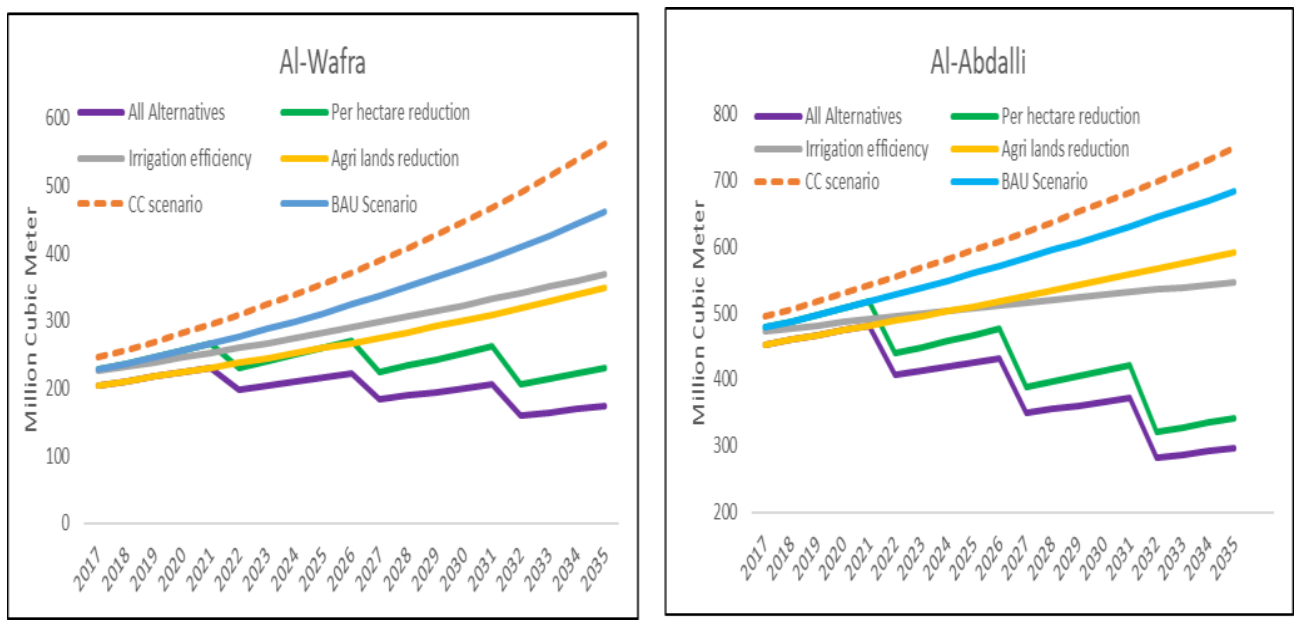

Figure (7): Comparison among intervention management

The increase in water demand in the domestic and agriculture sectors will lead to an expansion in desalination plants, which in turn would increase the electricity for producing water to bridging between supply and demand. Consequently, increasing water and electricity due to population and economic growth rate as well as changing of lifestyle patterns consumption. The municipal (which is Kuwaiti governorates) calculated model shows that using advanced technology will decrease electricity consumption by about $70 \%$, this is due to the higher efficiency of RO over MSF technology (figure 9). Likewise, per capita reduction strategic option will decrease total electricity consumption about 61 million $\mathrm{kWh}$ by the year 2035 compare to BAU scenario. About 34 million $\mathrm{kWh}$ would be reduced by adopting water 
Journal of Environmental Sciences (JES)

Institute of Environmental Studies and Research, Ain Shams University

Hamed Abbass et al.

devices strategic alternative in the year 2035. Similarly, population control option will contribute to reduction in electricity consumption at the end of year 2035 about 29 million $\mathrm{kWh}$ as represented in figure (9).

The agricultural electricity model shows that the optimum strategic alternative in Al-Wafra territory. Figure (10) per capita hectare reduction, would save about $50 \%$ of electricity consumption, followed by agriculture land control option, which will reduce electricity consumption by around $22 \%$ in the year 2035. The third option for saving electricity will increase irrigation efficiency and using RO technology, which reduces electricity consumption by about $18 \%$ and $17 \%$ respectively. The results in Al-Abdali area is slightly different with adoption of RO technology option. It will reduce greater than irrigation efficiency $25 \%$ and $19 \%$ respectively due to desalination water used in Al-Abdali more than Al-Wafra. In the year 2035 per capita, option will participate in reduce electricity consumption percentage as well as land control alternative will economize only $13 \%$. 
Journal of Environmental Sciences (JES)

Institute of Environmental Studies and Research, Ain Shams University

Hamed Abbass et al.
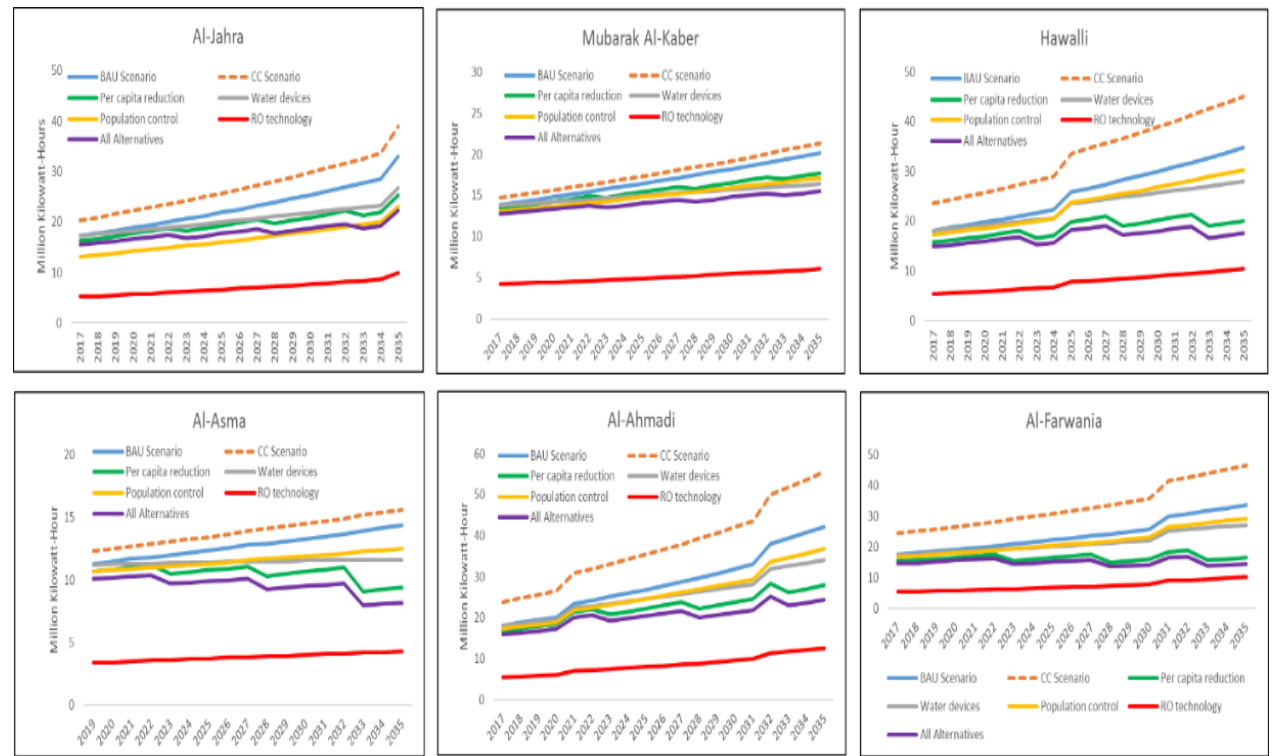

Figure (8): water and electricity intervention scenarios
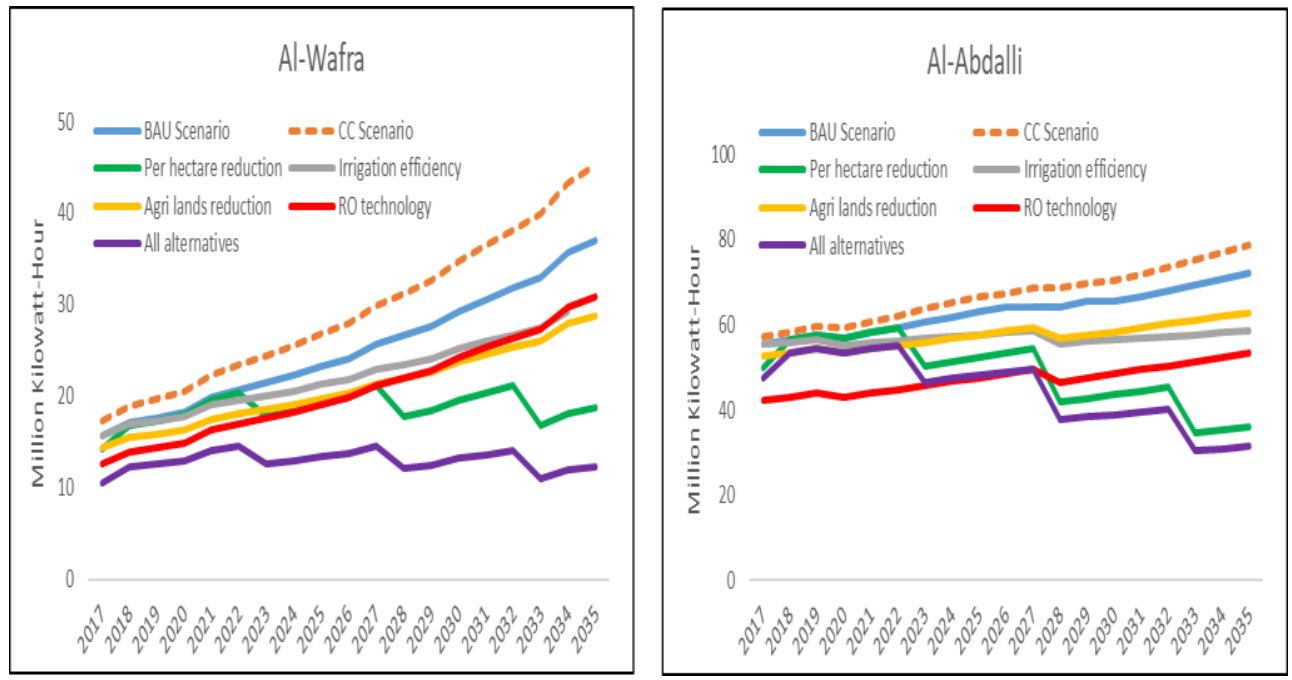

Figure (9): Interventions scenarios in agricultural areas

Vol.(49); Iss.(9); No.(7); Sept. 2020 


\section{Cost Implications:}

Emissions Cost: The burning of fossil fuels from the desalination plant to produce water and extraction groundwater as well as treated wastewater through electricity uses have led to more air pollution and Green House Gases (GHG) Emissions. GHGs have occurred released emissions concentrations via water processes and that titled as a carbon footprint. This includes nitrogen dioxide $\left(\mathrm{NO}_{2}\right)$, sulfur dioxide $\left(\mathrm{SO}_{2}\right)$, and carbon dioxide $\left(\mathrm{CO}_{2}\right)$ (Dawoud and Mulla, 2012 and Liu, et al. 2015). Table (5-5) illustrates estimation of total GHG emissions for producing cubic meter, which is the range between 3 to $20 \mathrm{kgCO}_{2} / \mathrm{m}^{3}$ as well as 0.32 to $0.60 \mathrm{kgCO}_{2} / \mathrm{kWh}$. The lowest value was chosen in this research.

Table (4) Estimate of total GHG emission by technology to produce one $\mathrm{m}^{3}$

\begin{tabular}{|c|c|c|c|}
\hline \multirow{2}{*}{ Cost } & \multicolumn{2}{|c|}{ Technology } & Sources \\
\hline \hline \multirow{5}{*}{ Greenhouse Gases } & $\mathrm{MSF}$ & $\mathrm{RO}$ & \\
\cline { 2 - 5 } & $\begin{array}{c}2.988 \\
\mathrm{kgCO}_{2} / \mathrm{m}^{3} / \mathrm{m}^{3}\end{array}$ & $\begin{array}{c}2.562 \\
\mathrm{kgCO}_{2} / \mathrm{m}^{3}\end{array}$ & (Liu, et al. 2015) \\
\cline { 2 - 5 } & $10 \mathrm{to} 20^{\mathrm{CO}_{2}} \mathrm{~m}^{3}$ & 2.8 to $3.6^{\mathrm{CO}_{2} \mathrm{~m}^{3}}$ & (Sommariva 2010) \\
\cline { 2 - 5 } & $\mathrm{kg}^{2} / 32 \mathrm{~kg}$ & & (Sokolow, Godwin and \\
\cline { 2 - 4 } & $\mathrm{CO}_{2} / \mathrm{kWh}$ & & Cole 2016) \\
\cline { 2 - 5 } & $0.604 \mathrm{~kg}$ & & (Sahely, et al. 2006) \\
\hline
\end{tabular}

The total emissions from producing, conveying, extraction, and treated water will increase in the future. Those emissions are the main causes of air pollution due to burning fossil fuel, especially from desalination plants. $\mathrm{CO}_{2}$ estimations between years 2017 and 2035 will rise gradually concurrently 520 
with climate change effluences as presented in table (6). This table shows that $\mathrm{CO}_{2}$ emissions are double during 2006-2035, on average from 1.5 to 3 million-ton $\mathrm{CO}_{2}$. Specifically, about 65 million-ton of $\mathrm{CO}_{2}$ produced from the water system through this period was emitted to the air. A $20 \%$ of total emission comes from Al-Ahmadi governorate then $18 \%$ from Hawalli, Mubarak Al-Kaber, and Al-Jahra respectively, and at the last Al-Asma only produced $12 \%$.

Thus, the total cost of carbon emissions by adopting interventional water strategic alternatives would decrease the released emissions. These options compared to business as usual scenario will contribute to reducing $\mathrm{CO}_{2}$ emissions about $75 \%$ in Mubarak Al-Kaber governorate. If all interventions have adopted, the greater percentage will be in Al-Jahra about 67\%. Then, those interventions will assist Al-Ahmadi, Al-Asma, and Hawalli for reducing their emissions about $58 \%, 57 \%$, and $51 \%$ respectively.

Table (5): Estimations of $\mathrm{CO}_{2}$ emission in the year 2035

\begin{tabular}{|c|c|c|c|c|c|c|}
\hline & $\begin{array}{c}\text { Al- } \\
\text { Jahra }\end{array}$ & $\begin{array}{c}\text { Al- } \\
\text { Ahmadi }\end{array}$ & $\begin{array}{c}\text { Al- } \\
\text { Asma }\end{array}$ & Hawalli & $\begin{array}{c}\text { Mubarak } \\
\text { Al-Kaber }\end{array}$ & $\begin{array}{c}\text { Al- } \\
\text { Farwania }\end{array}$ \\
\hline Climate Change & 515 & 665 & 305 & 597 & 360 & 617 \\
\hline BAU & 438 & 504 & 281 & 456 & 341 & 444 \\
\hline Population control & 380 & 438 & 243 & 399 & 287 & 386 \\
\hline Water devices & 349 & 402 & 224 & 365 & 272 & 355 \\
\hline Per capita reduction & 336 & 334 & 184 & 266 & 299 & 219 \\
\hline All Alternatives & 292 & 290 & 159 & 231 & 257 & 190 \\
\hline $\begin{array}{c}\text { Reduction compare } \\
\text { to BAU scenario \% }\end{array}$ & 67 & 58 & 57 & 51 & 75 & 43 \\
\hline
\end{tabular}




\section{RECOMANDATIONS}

Kuwait needs rapid steps toward achieving water, energy, and food management sustainability as well as integration strategy. This strategy should include several procedures such as,

1. Water, energy, and food guidelines portfolio.

2. Developing consistent water, energy, and food data reporting standards

3. Develop water, energy, and food partnerships between government, private, and Non-governmental entities.

\section{REFERENCES}

Salzen, Knut von, John F Scinocca, Norman A McFarlane, Jiangnan Li, Jason N Cole, David Plummer, Diana Verseghy, et al. (2013): The Canadian Fourth Generation Atmospheric Global Climate Model (CanAM4). Part I: Representation of Physical Processes. Atmosphere-Ocean 1.4-125.

Alberta, University of. (2018): The development of an integrated model for the assessment of water and GHG footprints for the power generation sector. Environmental Studies, Atlanta: NewsRx.

AlSabbagh, M., Y. Siu, A. Guehnemann, and J. Barrett. (2015): Mitigation of $\mathrm{CO} 2$ emissions from the road passenger transport sector in Bahrain. Mitigation \& Adaptation Strategies for Global Change 99-119.

Amin, Ali, Javed Iqbal, Areesha Asghar, and Lars Ribbe. (2018): Analysis of Current and FutureWater Demands in the Upper Indus Basin under IPCC Climate and Socio-Economic Scenarios Using a Hydro-Economic WEAP Model." MDPI (Water). 
CHOVERT, ANGEL D., and MARCELO F. ALONSO. (2017): Estimated evolution of total pollutant gas emissions associated with vehicle activity in the Metropolitan Region of Porto Alegre until 2030." Anais da Academia Brasileira de Ciências 1971-1983.

Dale, Larry L., Nihan Karali, Dev Millstein, Mike Carnall, Sebastian Vicuña, Nicolas Borchers, Eduardo Bustos, et al. (2015): An integrated assessment of water-energy and climate change in sacramento, california: how strong is the nexus? Climatic Change 223-235.

Dawoud, Mohamed A, and Mohamed M Mulla (2012): Environmental Impacts of Seawater Desalination: Arabian Gulf Case Study. Environment and Sustainability 22-37.

Dawoud, Mohamed A. (2018): Water and Energy Nexus in GCC Countries. In Recent Advances in Environmental Science from the EuroMediterranean and Surrounding Regions. Springer International Publishing AG.

DGCA. (2017): Climate of Kuwait (Measured and Projected changes). Kuwait, 12.

Kelemework, Amha Tesfaye. 2(018): Water-Energy Nexus Using Integrated Modeling Approach for Water Use by Power Sector in Etowah River Basin. Master Thesis, ProQuest LLC.

Kim, Hana (2018): Economic and environmental implications of the recent energy transition on South Korea's electricity sector." Energy \& Environment 752-769.

Kishiwa, Peter, Joel Nobert, Victor Kongo, and Preksedis Ndomba. (2018): "Assessment of impacts of climate change on surface water availability using coupled SWAT and WEAP models: case of upper Pangani River Basin, Tanzania." International Association of Hydrological Sciences (PIAHS) 23-27. 
Kou, Limin, Xiangyang Li, Jianyi Lin, and Jiefeng Kang. (2018): Simulation of Urban Water Resources in Xiamen Based on a WEAP Model." MDPI (Water).

Li, Xinyue (2014): Understanding the water-energy nexus: a case study of ningxia. PhD Thesis, Ann Arbor: ProQuest Dissertations \& Theses Global.

Liu, Jiahong, Silan Chen, Hao Wang, and Xiangdong Chen. (2015): Calculation of carbon footprints for water diversion and desalination projects. Energy Procedia 2483-2494.

Sahely, Halla R, L Heather Maclean, D Hugh Monteith, and David M Bagley. (2006): Comparison of on-site and upstream greenhouse gas emissions from Canadian municipal wastewater treatment facilities." Environmental Engineering and Science 405-415.

SEI. (2018): WEAP. 7.

SEIb. (2018): 7 2. https://www.energycommunity.org/default.asp? action=introduction.

Sieber, Jack, and Charlie Heaps. (2017): Integrating WEAP and LEAP Tools for Modeling Energy-Water Connections. https://www.sei.org/.

Slaughter, Andrew R., and Sukhmani K. Mantel (2018): Water quality modelling of an impacted semi-arid catchment using flow data from the WEAP model. The International Association of Hydrological Sciences (PIAHS) 25-33.

Sokolow, S, H Godwin, and B L Cole (2016): Impacts of urban water conservation strategies on energy, greenhouse gas emissions, and health: Southern california as a case study." American Journal of Public Health 941-948.

Sommariva, C. (2010): Efficiency Improvements in Power Desalination For Better Environmental Impact. Jeddah Kingdom of Saudi Arabia. 
Yates, David, and Kathleen A Miller (2013): Integrated Decision Support for Energy/Water Planning in California and the Southwest. The International Journal of Climate Change: Impacts and Responses 49-63.

Daher, B. (2012): Water, Energy, and Food Nexus: A Basis for Strategic Planning for Natural Resources. Purdue University.

Hussey, K., \& Pittock, J. (2012): The energy-water nexus: Managing the links between energy and water for a sustainable future. Ecology and Society, 17(1). http://doi.org/10.5751/ES-04641-170131.

Jalilov, S. M., Amer, S. a., \& Ward, F. A. (2013): Water, Food, and Energy Security: An Elusive Search for Balance in Central Asia. Water Resources Management, 27(11), 3959-3979. http://doi.org/10.1007/s11269-013-0390-4.

Villamayor-Tomas, S., Epstein, G., Evans, T., \& Kimmich, C. (2015): The Water-Energy-Food Security Nexus through the Lenses of the Value Chain and the Institutional Analysis and Development Frameworks. Water Alternatives 8(1):, 8(1), 735-755.

FAO. (2014): The Water-Energy-Food Nexus.

IISD. (2013): The Water-energy-food Security Nexus: Towards a Practical Planning and Decision-support Framework for Landscape Investment and Risk Management. Retrieved from http://www.iisd.org/sites/default/files/pdf/2013/wef_nexus_2013. pdf 


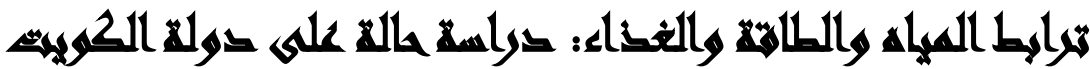

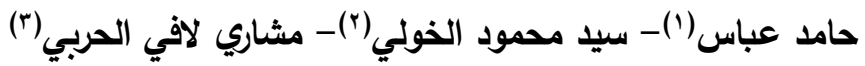

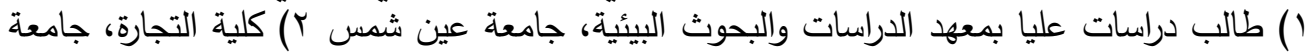 \\ عين شمس ץ) كلية العلوم الحياتية، جامعة الكويت
}

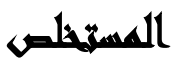

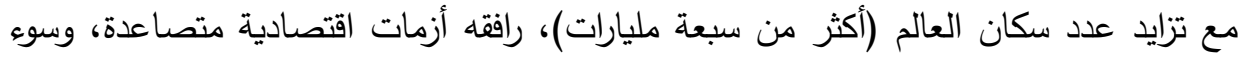

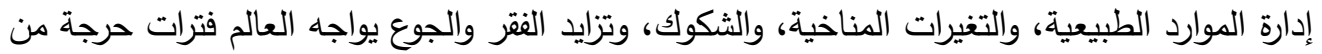
التحديات الخطيرة. تهدف هذه الورقة إلى تطوير نموذج ديناميكي متكامل لنظام المياه والطاقة والفئات والغذاء

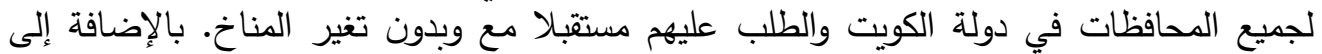

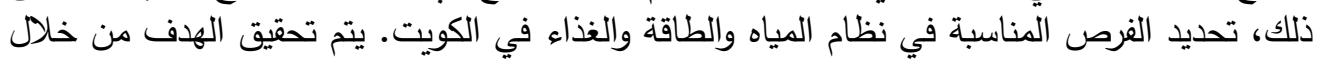

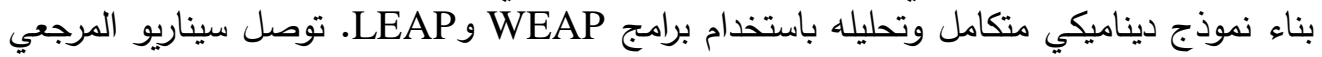

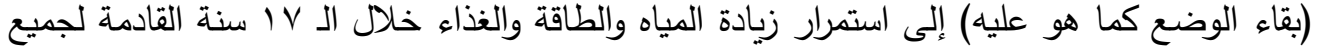

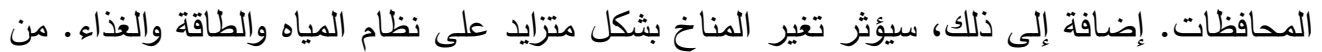

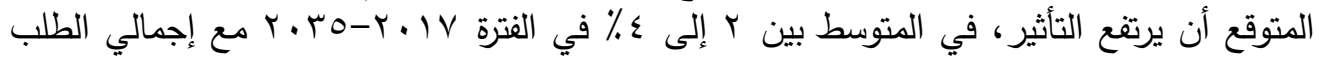

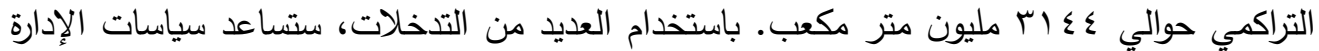

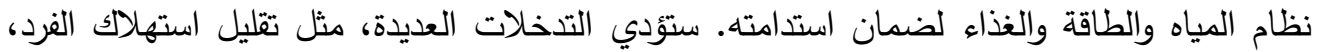

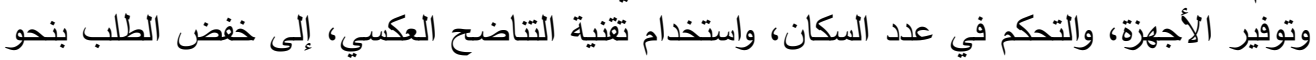

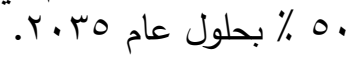
الكلمات الدالة: ترابط المياه والطاقة والغذاء، LEAP and WEAP، تغير المناخ. 